\title{
ANALISIS EFISIENSI DISTRIBUSI PADA PENJUALAN PRODUK OLAHAN BUAH DAN SAYURAN DENGAN METODE DATA ENVELOPMENT NALYSIS (DEA)
}

\author{
Silvana Maulidah, Fitri Megayanti \\ Program Studi Agribisnis, Fakultas Pertanian, Universitas Brawijaya \\ silvana.maulidah@yahoo.com
}

Received: 30 Juli 2016; Accepted: 20 Oktober 2016; Published: 30 Oktober 2016

DOI: http://dx.doi.org/10.21107/agriekonomika.v5i2.1594

\begin{abstract}
ABSTRAK
Setiap agroindustri memerlukan distribusi pemasaran yang efisien sehingga memudahkan konsumen untuk mendapatkan produk dan dapat mengoptimalkan keuntungan untuk mewujudkan pangsa pasar yang luas. Tujuan dari penelitian ini yaitu mengidentifikasi saluran distribusi pemasaran, menganalisis tingkat efisiensi distribusi, dan merumuskan strategi perbaikan tingkat efisiensi distribusi yang tidak efisien menggunakan metode Data Envelopment Analysis (DEA) dengan bantuan software WDEA (Warwick DEA). Batasan dalam pengukuran efisiensi pada penelitian ini adalah variabel input dan output. Variabel input meliputi jumlah retailer, volume pengiriman, dan biaya distribusi. Variabel output meliputi volume penjualan, penerimaan, dan keuntungan. Hasil dari analisis efisiensi distribusi pada penjualan produk olahan buah dan sayuran adalah sebagai berikut: (1) saluran distribusi yang digunakan adalah saluran distribusi nol tingkat dan saluran distribusi satu tingkat. (2) Terdapat delapan saluran distribusi yang efisien meliputi wilayah Malang, Batu, Kediri, Tuban, Magelang, Jombang, Lumajang, dan Surabaya. erdapat tujuh wilayah saluran distribusi yang tidak efisien yaitu Blitar, Banyuwangi, Bojonegoro, Trenggalek, Lamongan, Ponorogo, dan Mojokerto. (3) Strategi perbaikan pada saluran distribusi yang tidak efisien adalah sebagai berikut: (a)menurunkan volume pengiriman sesuai dengan nilai target efisiensi; (b) meningkatkan volume penjualan sesuai dengan target efisiensi agar tidak terjadi penumpukan produk sehingga dapat meningkatkan penerimaan dan keuntungan agroindustri, dan (c) menambah jumlah retailer pada wilayah distribusi yang tidak efisien.
\end{abstract}

Kata Kunci: Saluran distribusi, efisiensi, Data Envelopment Analysis (DEA)

\section{DISTRIBUTION EFFICIENCY ANALYSISON SELLING OFPROCESSING PRODUCT OF FRUITS AND VEGETABLES BY USING DATA ENVELOPMENT ANALYSIS( DEA) METHOD}

\begin{abstract}
Industrial agro requires efficient marketing distribution making it easier for consumers to get their products and can optimize the benefits to achieve a large market share. The purposes from this research is to identify the distributional channel toward fruit and vegetable processing product sale, to analyze the efficient rate on fruit and vegetable processing product, and to formulate the distributional efficiency rate improvement strategy which is not efficient using Data Envelopment Analysis (DEA) is done by WDEA (Warwick DEA) Software. Limitations in the efficiency measurement in this study is the input and output variables. Input variables include the number of retailers, delivery volume, and distribution costs. Variable output includes the volume of sales, revenue and profits. The result of distributinal efficiency analysis toward fruit and vegetables processing product selling namely: (1) used are zero-rate and one rate distributional channeling. (2) There are 8 distributional channeling which is efficient includes in Malang, Batu, Kediri, Tuban, Magelang, Jombang, Lumajang and Surabaya. Meanwhile 7 distributional channeling area which is not efficient are Blitar, Banyuwangi, Bojonegoro, Trenggalek, Lamongan, Ponorogo, and Mojokerto. (3) Improvement strategy toward distributional channeling area which is not efficient are explained below: (a) decrease the sending volume according to the efficiency target; (b) increase the selling volume based on the efficiency target in order not to get heaping on product so it can give advantage for industrial agro; and (c) add the total of retailer toward distributional area which is not efficient.
\end{abstract}

Keywords: Distribution channels, efficiency, Data Envelopment Analysis (DEA).

Corresponding author:

Address : Jl. Blimbing Indah Timur F4-19 Malang

Email : silvana.maulidah@yahoo.com

(C) 2016 Universitas Trunojoyo Madura

Phone : 081334353744 


\section{PENDAHULUAN}

Agroindustri merupakan satu sistem dalam subsistem agribisnis dengan menggunakan bahan baku komoditas pertanian, atau industri yang tidak terpisahkan dari kegiatan sektor pertanian dalam arti luas (Rahardi, 2003). Peran agroindustri dalam memacu perekonomian dapat dilihat dari banyaknya agroindustri yang bermunculan dan mengembangkan usahanya (Sastradipoera. 2003). Namun demikian, usaha skala mikro seringkali terkendala berbagai permasalahan terutama dibidang pemasaran, apalagi dalam kondisi harus bersaing dengan perusahaan skala menengah ataupun indusri skala besar lainnya (Hidayati, 2016). Salah satu usaha yang berperan penting dalam keberhasilan perusahaan adalah menerapkan manajemen pemasaran untuk dapat menguasai pangsa pasar secara luas. Pemasaran merupakan muara akhir dari suatu aktivitas produksi, untuk memperoleh nilai harga barang produksi guna melanjutkan usaha dikemudian hari dan menciptakan kesejahteraan pengguna (Wibow, 2016). Sedangkan Simamora (2003), menyatakan bahwa manajemen pemasaran merupakan suatu kegiatan yang dilakukan oleh individu maupun kelompok dalam pengelolaan proses sosial dan manajerial dengan cara pertukaran produk maupun jasa dengan pihak lain yang bertujuan untuk memenuhi kebutuhan dan keinginan konsumen serta dapat menguntungkan perusahaan. Dalam manajemen pemasaran, terdapat strategi untuk memenangkan persaingan, yaitu bauran pemasaran (marketing mix), yang salah satunya adalah place, atau disebut juga distribusi pemasaran. Guna mewujudkan pangsa pasar tersebut, setiap agroindustri atau perusahaan memerlukan distribusi pemasaran yang efisien. Saladin (1996), mengemukakan bahwa saluran distribusi merupakan suatu struktur bisnis dari organisasi yang melakukan semua kegiatan yang digunakan untuk menyalurkan produk dari produsen ke konsumen. Penentuan saluran distribusi yang tepat dan efisien dapat memudahkan konsumen untuk mendapatkan produk (Stanton, 1993).
Salah satu perusahaan yang melakukan distribusi pemasaran ke berbagai daerah adalah CV. Cita Mandiri. Agroindustriini memproduksi olahan buah dan sayuran yang berupa keripik, stik, kerupuk, dan supplier buah dan sayuran segar, bibit buah dan sayuran. Wilayah pemasaran olahan buah dan sayuran yang diproduksi meliputi wilayah Bojonegoro, Lamongan, Banyuwangi, Kediri, Malang, Mojokerto, Ponorogo, Batu, Lumajang, Surabaya, Trenggalek, Blitar, Jombang, Magelang, dan Tuban. kegiatan efisiensi distribusi pemasaran produk penting dilakukan. Hal ini dikarenakan dapat membantu perusahaan dalam pengambilan keputusan distribusi produk olahan buah dan sayuran ke berbagai wilayah. Agroindustri ini dihadapkan pada kondisi persaingan pasar, mengingat maraknya perusahaan olahan buah dan sayuran serta fenomena produk olahan buah dan sayuran yang semakin digemari oleh konsumen sehingga dapat memungkinkan semakin banyak pelaku usaha atau produsen olahan buah dan sayuran yang bermunculan, baik di Kota Batu maupun di wilayah lainnya.

Sebagaimana diketahui, produk pertanian pada umumnya mempunyai ciri-ciri yang mudah rusak sehingga untuk mempertahankan kualitas dan kuantitas produk pada setiap pendistribusian produk, perusahaan harus mampu menentukan saluran distribusi yang paling efektif dan efisien (Sujana, 2005). Biaya distribusi juga diperhitungkan demi mencapai keuntungan yang optimal dan biaya yang seminimal mungkin (Gaspersz, 2005). Berdasarkan uraian tersebut, penelitian ini bertujuan untuk mengidentifkasi saluran distribusi pemasaran, menganalisis tingkat efisiensi distribusi, dan merumuskan strategi perbaikan tingkat efisiensi distribusi yang tidak efisien.

\section{METODE PENELITIAN}

Penelitian dilaksanakan pada CV.Cita Mandiri yang berlokasi di Jl.Trunojoyo No. 20 Perum Rejoso, Kecamatan Junrejo, Kota Batu, Jawa Timur. Lokasi ini dipilih 
disesuaikan dengan tujuan dan karakteristik penelitian sehingga sesuai untuk dilakukan penelitian terkait efisiensi distribusi pemasaran produk. Penentuan responden menggunakan teknik purposive dan informasi penelitian diperoleh melalui key informan (sumber informasi) yaitu pemilik agroindustri dan manajer pemasaran.

Metode pengumpulan data pada penelitian ini yaitu wawancara, observasi dan dokumentasi. Data yang digunakan adalah data primer dan sekunder. Metode analisis data dalam penelitian ini yaitu metode analisis data secara deskriptif untuk mengidentifikasi saluran distribusi pada penjualan produk olahan buah dan sayuran dan metode analisis data kuantitatif dengan cara mengklasifikasikan, membandingkan, dan menghitung data yang berupa angka dengan rumus yang relevan yakni menggunakan metode Data Envelopment Analysis (DEA) dengan bantuan software Warwick DEA. Adapun tahapan yang dilakukan yaitu:

1. Penentuan Decition Making Unit (DMU)

Penentuan DMU dalam penelitian ini yaitu wilayah distribusi yang menjadi tujuan dari saluran distribusi pemasaran olahan buah dan sayuran yakni pada wilayah Batu, Malang, Surabaya, Bojonegoro, Lamongan, Blitar, Trenggalek, Banyuwangi, Ponorogo, Kediri, Jombang, Lumajang, Magelang, Mojokerto, dan Tuban. Setiap DMU tersebut akan dibandingkan dengan DMU lainnya sehingga dapat diketahui DMU yang lebih efisien.

2. Identifikasi Variabel Input dan Output

Penentuan variabel input dan output dalam penelitian ini berdasarkan hasil wawancara dengan responden dan penelitian terdahulu. Variabel input merupakan sumber daya yang digunakan untuk menjalankan fungsi dalam pendistribusian produk olahan buah dan sayuran. Variabel output merupakan hasil dari kegiatan pendistribusian yang telah dilakukan. Variabel input meliputi; jumlah retailer, volume pengiriman, dan biaya distribusi. Sedangkan variabel output meliputi: volume penjualan, penerimaan, dan keuntungan agroindustri dari hasil pendistribusian produk.

3. Uji Korelasi Faktor

Uji korelasi faktor untuk mengetahui hubungan antara beberapa faktor, dimana suatu faktor tersebut dapat memiliki nilai yang tergantung dari faktor yang lain sehingga faktor tersebut dapat diwakilkan. Pengukuran korelasi faktor menggunakan Software SPSS. Penelitian ini menggunakan Correlate Bivariate karena parameter yang digunakan adalah nilai dari Pearson Correlation. Jika nilai Pearson Correlation mendekati 1 maka variabel yang diteliti memiliki keterkaitan yang kuat dengan variabel pembanding. Adapun interval koefisien tingkat hubungan ditunjukkan pada Tabel 1.

\section{Data Envelopment Analysis (DEA)}

Data Envelopment Analysis (DEA) dapat digunakan untuk mengetahui seberapa efisien sebuah DMU yang digunakan dengan pemanfaatan sumberdaya yang ada untuk dapat menghasilkan output yang maksimum (Ray, 2004). Penelitian ini menggunakan model orientasi terhadap input dan output dan model DEA Variabel Return To Scale (VRS) dengan asumsi bahwa setiap penambahan input tidak menghasilkan output yang proporsional, sehingga efisiensinya bisa naik atau turun. Model tersebut digunakan dalam penelitian ini karena agroindustri yang diteliti

Tabel 1

Interval Koefisien Tingkat Hubungan

\begin{tabular}{cc}
\hline Interval Koefisien & Tingkat Hubungan \\
\hline $0,000-0,199$ & Sangat Rendah \\
$0,200-0,399$ & Rendah \\
$0,400-0,599$ & Sedang/cukup \\
$0,600-0,799$ & Kuat \\
$0,800-1,000$ & Sangat Kuat
\end{tabular}

Sumber: Ridwan, 2005, dalam Sarjono dan Julianita, 2011 
mempunyai kondisi yang belum optimal. Skor efisiensi yang digunakan adalah antara 0 dan $100 \%$, dengan ketentuan tingkat efisiensi yang sempurna adalah skor $100 \%$ sedangkan tingkat inefisiensi yang paling rendah adalah skor $0 \%$. Terdapat tiga kondisi dalam hasil perhitungan DEA pada Tabel 2.

5. Strategi Perbaikan

Strategi perbaikan merupakan tahapan selanjutnya dalam metode DEA yang digunakan untuk memperbaiki saluran distribusi yang tidak efisien hingga menjadi efisien. Strategi perbaikan dilakukan menggunakan software WDEA (Warwick DEA). Melalui hasil output dapat dilihat nilai aktual, nilai target dan prosentase perbaikan antara input dan output sehingga dapat diketahui variabel input dan variabel output yang harus diperbaiki untuk meminimalkan input, mengoptimalkan output dan memperoleh hasil yang efisien.

\section{HASIL DAN PEMBAHASAN}

\section{Profil Agroindustri}

Cita Mandiri merupakan perusahaan home industry yang bergerak dalam bidang per- tanian. Agroindustri ini memulai usahanya pada tanggal 1 Januari 1992 berlokasi di Jl. Trunojoyo No. 20 Perum Rejoso, Kecamatan Junrejo, Kota Batu, Jawa Timur. Agroindustri ini berupaya untuk menjadi distributor aneka produk olahan buah dan sayuran dengan merk dagang "CM". Agroindustri ini memasarkan produk olahan dari buah dan sayuran yang berupa keripik buah dan keripik sayuran, kerupuk buah dan kerupuk sayuran, serta stik buah dan stik sayuran. Berbagai macam produk tersebut hingga sampai saat ini menjadi produk utama dan menjadi olahan yang diminati oleh konsumen. Wilayah saluran distribusi pada agroindustri ini meliputi wilayah Batu, Malang, Kediri, Ponorogo, Magelang, Mojokerto, Lamongan, Tuban, Bojonegoro, Surabaya, Trenggalek, Banyuwangi, Blitar, Lumajang, dan Jombang.

\section{Saluran Distribusi}

Saluran distribusi pemasaran yang digunakan agroindustri ini yaitu dua saluran distribusi meliputi saluran distribusi nol tingkat dan saluran distribusi satu tingkat. Menurut Kotler (1983), saluran distribusi nol tingkat merupakan saluran distribusi

Tabel 2

Kondisi Efisiensi Hasil Perhitungan DEA

\begin{tabular}{|c|c|c|c|c|}
\hline No & Range Condition & Score (\%) & Efisiensi & Keterangan \\
\hline 1. & Range red & $0-89,99$ & $\begin{array}{l}\text { Tidak } \\
\text { Efisien }\end{array}$ & $\begin{array}{l}\text { Kondisi proyek beresiko karena } \\
\text { jauh dari score yang ingin dicapai, } \\
\text { sehingga perlu adanya tindakan } \\
\text { manaiemen. }\end{array}$ \\
\hline 2. & Range amber & $90-99,99$ & $\begin{array}{l}\text { Tidak } \\
\text { Efisien }\end{array}$ & $\begin{array}{l}\text { Kondisi proyek mungkin beresiko jika } \\
\text { permasalahan yang ada tidak segera } \\
\text { ditangani, sehingga memerlukan } \\
\text { perhatian yang khusus. }\end{array}$ \\
\hline 3. & Range green & 100 & Efisien & $\begin{array}{l}\text { Kondisi proyek aman dan terdapat } \\
\text { score yang sesuai dengan harapan. } \\
\text { Terdapat dua orientasi efisiensi yaitu: } \\
\text { a. Efisiensi dari orientasi output } \\
\text { yaitu output naik pada saat } \\
\text { input tetap atau output dalam } \\
\text { keadaam tetap pada saat input } \\
\text { turun. } \\
\text { b. Efisiensi dari orientasi input } \\
\text { yaitu keadaan input tetap pada } \\
\text { saat output turun atau keadaan } \\
\text { input turun pada saat output }\end{array}$ \\
\hline
\end{tabular}


pemasaran yang paling sederhana dan paling pendek karena tidak menggunakan perantara dalam penyampaian produk. Agroindustri selaku produsen melakukan penjualan langsung ke konsumen dengan cara melayani konsumen yang datang langsung ke lokasi agroindustri. Dampak positif pada saluran distribusi nol tingkat yaitu sistem pembayaran yang dilakukan secara tunai, namun saluran distribusi ini hanya mendistribusikan dengan prosentase $10 \%$. Adapun dampak negatif bagi agroindustri yaitu harga yang ditawarkan ke konsumen tidak sama dengan harga yang ditawarkan ke retailer. Selain itu, pangsa pasar pada saluran distribusi nol tingkat tidak dapat meluas karena konsumen sebagian besar berasal dari masyarakat sekitar wilayah agroindustri.

Saluran distribusi satu tingkat yang dilakukan yaitu agroindustri ini selaku produsen menyalurkan produk ke retailer, dari pihak retailer kemudian dipasarkan ke konsumen. Agroindustri selaku produsen menjualkan produk ke retailer dengan cara mengirimkan produk yang telah dipesan oleh retailer dengan pertimbangan biaya distribusi dan jumlah produk yang dikirimkan. Proses pengiriman produk dilakukan dalam periode satu bulan sekali sesuai dengan pesanan setiap wilayah distribusi. Dampak positif pada saluran distribusi satu tingkat yaitu harga yang ditawarkan ke retailer lebih tinggi,.volume penjualan produk lebih tinggi dan pangsa pasar dapat meluas ke berbagai retailer di dalam maupun di luar kota Batu dengan prosentasi $90 \%$. Adapun dampak negatif bagi agroindustri yaitu sistem pembayaran yang dilakukan tidak secara tunai sehingga mengalami kemunduran waktu dalam perolehan penerimaan.

\section{Analisis Efisiensi Distribusi}

Efisiensi distribusi merupakan sebagai usaha untuk mencapai hasil distribusi yang optimal dengan menggunakan sumber daya yang tersedia dalam suatu waktu (Wirapati dalam Setyo Budi, 2010). Analisis efisiensi distribusi digunakan untuk menganalisis saluran distribusi yang dimi- liki suatu perusahaan, khususnya agroindustri ini dengan memanfaatkan saluran yang ada untuk mencapai output yang optimum. Tujuan analisis efisiensi distribusi yaitu untuk mengetahui tingkat efisiensi pada setiap wilayah saluran distribusi, sehingga apabila terdapat saluran distribusi yang tidak efisien maka dapat diperbaiki sehingga menjadi efisien.

\section{Penentuan Decision Making Unit (DMU)}

Decision Making Unit (DMU) merupakan sebuah kumpulan unit-unit pembuat keputusan dalam mengelola sumber daya input sehingga menghasilkan output (Pratiwi, 2009). DMU digunakan untuk menentukan unit-unit yang akan diukur dalam pengukuran efisiensi distribusi.Wilayah distribusi yang digunakan pada penelitian ini yaitu 15 wilayah. Jumlah wilayah tersebut lebih besar dari jumlah variabel input dan variabel output, karena jumlah DMU yang ditentukan harus lebih besar dari jumlah variabel yang ditentukan. Adapun penentuan DMU pada masing-masing wilayah saluran distribusi dapat dilihat pada Tabel 3.

Pengumpulan data yang akan diolah menunjukkan bahwa agroindustri ini mempunyai $15 \mathrm{DMU}$, sehingga data yang digunakan untuk analisis efisiensi dianggap cukup atau sudah memenuhi. Klasifikasi DMU yang tertera pada tabel diatas dilakukan agar mempermudah pembagian objek dari daerah penelitian. Selain itu, klasifikasi DMU diperlukan untuk dapat dilakukan perhitungan efisiensi pada setiap wilayah distribusi.

\section{Identifikasi Variabel Input dan Variabel Output}

Identifikasi variabel input dan output pada penelitian ini didasarkan pada hasil wawancara langsung terhadap responden dan studi literatur. Adapun penentuan variabel input berdasarkan pertimbangan sumber daya yang mempengaruhi kinerja dari DMU saluran distribusi. Sedangkan penentuan variabel output berdasarkan hasil yang diperoleh dari kinerja DMU saluran distribusi. Adapun variabel input dan output yang digunakan pada penelitian ini ditunjukkan pada Tabel 4. 
Tabel 3

Wilayah Distribusi Pemasaran CV. Cita Mandiri

\begin{tabular}{|c|c|c|}
\hline No & Wilayah Distribusi Pemasaran & DMU \\
\hline 1. & & DMU 1 \\
\hline 2. & IValang & DMU 2 \\
\hline 3. & Blitar & DMU 3 \\
\hline 4. & Batu & DMU 4 \\
\hline 5. & Banyuwangi & DMU 5 \\
\hline 6. & Bojonegoro & DMU 6 \\
\hline 7. & $\begin{array}{l}\text { Irenggalek } \\
\text { Kediri }\end{array}$ & DMU 7 \\
\hline 8. & Kearri & DMU 8 \\
\hline 9. & Maqelang & DMU 9 \\
\hline 10. & IVlagelang & DMU 10 \\
\hline 11. & Lamongan & DMU 11 \\
\hline 12. & Ponorogo & DMU 12 \\
\hline 13. & Nojokerto & DMU 13 \\
\hline 14. & Jombang & DMU 14 \\
\hline 15. & Surabava & DMU 15 \\
\hline
\end{tabular}

Sumber: Data Primer Diolah, 2016

Terdapat tiga variabel input dan tiga variabel output yakni lebih kecil dibandingkan jumlah DMU yang dimiliki agroindustri ini. Variabel input yakni: jumlah retailer, volume pengiriman, dan biaya distribusi. Variabel output yakni: volume penjualan, penerimaan, dan keuntungan. Adapun datanya sebagaimana berikut:

\section{Uji Korelasi Faktor}

Uji korelasi dilakukan untuk mengetahui tingkat kekuatan hubungan antara variabel input dan variabel output. Uji korelasi ini diharapkan dapat meminimalisir kesalahan data dalam memasukkan input dan output sehingga hasil tidak sesuai dengan harapan. Uji korelasi faktor dilakukan dengan menggunakan software SPSS 17 yaitu Correlation, Correlate Bivari- ate dengan parameter interval koefisien tingkat hubungan yaitu nilai 0,000-0,199 yang mempunyai tingkat hubungan yang sangat rendah, nilai 0,200-0,399 mempunyai tingkat hubungan yang rendah, nilai 0,400-0,599 mempunyai tingkat hubungan yang sedang atau cukup, nilai 0,600-0,799 mempunyai tingkat hubungan yang kuat dan nilai 0,800-1,000 mempunyai tingkat hubungan yang sangat kuat.Berdasarkan data hasil perhitungan variabel input dan output maka didapatkan hasil uji korelasi faktor yang ditunjukkan pada Tabel 6 .

Nilai korelasi Pearson antara variabel input dengan variabel output yaitudiantara 0,800-1,00. Hal ini menunjukan bahwa terdapat hubungan yang sangat kuat antara variabel input degan variabel output. Nilai signifikansi (2-tailed) sebesar

Tabel 4

Identifikasi Variabel Input dan Output

\begin{tabular}{cccc}
\hline & Simbol & Variabel & Satuan \\
\hline Input & X1 & Jumlah Retailer & Outlet \\
& X2 & Volume Pengiriman & Bungkus \\
& X3 & Biaya Distribusi & Rupiah \\
Output & Y1 & Volume Penjualan & Bungkus \\
& Y2 & Penerimaan & Rupiah \\
& Y3 & Keuntungan & Rupiah \\
\hline
\end{tabular}

Sumber: Data Primer, 2016 
Tabel 5

Data Variabel Input dan Variabel Output pada Periode Satu Bulan

\begin{tabular}{|c|c|c|c|c|c|c|c|}
\hline \multirow[b]{2}{*}{ No. } & \multirow[b]{2}{*}{ DMU } & \multicolumn{3}{|c|}{ INPUT } & \multicolumn{3}{|c|}{ OUTPUT } \\
\hline & & $\begin{array}{l}\text { Jumlah } \\
\text { Retailer } \\
\text { (Outlet) }\end{array}$ & $\begin{array}{c}\text { Volume } \\
\text { Pengiriman } \\
\text { (Bungkus) }\end{array}$ & $\begin{array}{c}\text { Biaya } \\
\text { Distribusi } \\
\text { (Rupiah) }\end{array}$ & $\begin{array}{c}\text { Volume } \\
\text { Penjualan } \\
\text { (Bungkus) }\end{array}$ & $\begin{array}{c}\text { Penerimaan } \\
\text { (Rupiah) }\end{array}$ & $\begin{array}{c}\text { Keuntungan } \\
\text { (Rupiah) }\end{array}$ \\
\hline 1. & Malang & 25 & 2.500 & 1.529 .800 & 2.350 & 30.598 .000 & 9.179 .400 \\
\hline 2. & Blitar & 11 & 608 & 419.600 & 494 & 6.996 .000 & 2.098 .800 \\
\hline 3. & Batu & 11 & 396 & 227.900 & 330 & 4.563 .500 & 1.369 .050 \\
\hline 4. & Banyuwangi & 8 & 968 & 1.085 .000 & 747 & 10.852 .500 & 3.255 .750 \\
\hline 5. & Bojonegoro & 8 & 500 & 376.600 & 320 & 4.185 .000 & 1.255 .500 \\
\hline 6. & Trenggalek & 8 & 350 & 296.700 & 300 & 3.713 .000 & 1.113 .900 \\
\hline 7. & Kediri & 7 & 708 & 527.400 & 452 & 8.790 .000 & 2.637 .000 \\
\hline 8. & Tuban & 7 & 350 & 421.900 & 350 & 4.219 .000 & 1.265 .700 \\
\hline 9. & Magelang & 5 & 691 & 832.100 & 533 & 8.321 .000 & 2.496 .300 \\
\hline 10. & Lamongan & 5 & 413 & 381.200 & 297 & 4.236 .000 & 1.270 .800 \\
\hline 11. & Ponorogo & 5 & 382 & 511.000 & 271 & 5.118 .000 & 1.535 .400 \\
\hline 12. & Mojokerto & 5 & 300 & 906.000 & 209 & 2.620 .000 & 786.000 \\
\hline 13. & Jombang & 5 & 165 & 155.900 & 165 & 2.228 .500 & 668.550 \\
\hline 14. & Lumajang & 4 & 316 & 484.000 & 316 & 4.840 .000 & 1.452 .000 \\
\hline 15. & Surabaya & 4 & 300 & 205.300 & 214 & 2.568 .000 & 770.400 \\
\hline & TOTAL & 118 & 8.947 & 8.360 .400 & 7.343 & 103.848 .500 & 31.154 .550 \\
\hline
\end{tabular}

Sumber: Data Sekunder Diolah, 2016

0,00 yang menunjukkan bahwa terdapat hubungan yang signifikan antara kedua variabel, hal ini dikarenakan nilai signifikansi $0,00<0,05$. Sedangkan korelasi yang terjadi antara kedua variabel tersebut adalah searah yang ditandai dengan nilai koefisien korelasi dengan notasi plus (+). Hubungan antara kedua variabel tersebut dapat disimpulkan bahwa terjadi hubungan yang kuat, signifikan dan terdapat hubungan linier yang positif atau searah.

\section{Data Envelopment Analysis(DEA)}

Pengukuran tingkat efisiensi distribusi produk olahan buah dan sayuran dilakukan dengan bantuan metode Data Envelopment Analysis (DEA). Analisis pengolahan data ini menggunakan data variabel input dan output yang telah ditentukan dan telah diuji tingkat hubungan antar variabel dengan analisa uji korelasi. Adapun analisis pengolahan data pada penelitian ini menggunakan bantuan software WDEA (Warwick DEA) untuk memudahkan perhitungan dengan kriteria skor perhitungan efisiensi yaitu apabila skor efisiensi yang diperoleh dalam perhitungan pada tiaptiap DMU bernilai $100 \%$.

Wilayah distribusi yang menjadi tujuan agroindustri ini yaitu wilayah Kediri, Ponorogo, Magelang, Malang, Mojokerto,
Lamongan, Tuban, Bojonegoro, Surabaya, Trenggalek, Banyuwangi, Batu, Blitar, Lumajang, dan Jombang. Wilayah tersebut merupakan wilayah retailer yang telah bekerjasama dengan agroindustri ini. Hasil perhitungan efisiensi distribusi dengan metode DEA ditunjukkan pada Tabel 8.

Berdasarkan nilai efisiensi pada DEA, terdapat tiga range condition yang mempunyai arti warna yang berbeda-beda antara lain:

1. Green merupakan proyek aman dan terdapat pada trek yang ingin dicapai.

2. Amber merupakan proyek yang mungkin beresiko jika masalah tersebut tidak ditangani sehingga memerlukan perhatian yang lebih pada kondisi ini.

3. Red merupakan proyek yang beresiko karena jauh dari trek yang ingin dicapai atau keluar dari ruang lingkup kondisi sehingga segera diperlukan tindakan manajemen.

Hasil pengukuran dari 15 DMU yang telah diuji menggunakan metode DEA, terdapat delapan wilayah distribusi yang efisien yaitu wilayah Batu, Jombang, Kediri, Lumajang, Magelang, Malang, Surabaya, dan Tuban. DMU yang dinyatakan efisien dikarenakan mempunyai nilai efisiensi $100 \%$ dengan kondisi aman dan 
Tabel 6

Hasil Uji Korelasi Variabel Input Dan Output

\begin{tabular}{ccccc}
\hline Keterangan & Hasil Uji Korelasi & $\begin{array}{c}\text { Volume } \\
\text { Penjualan }\end{array}$ & Penerimaan & Keuntungan \\
\hline Jumlah & Pearson Correlation & $.916^{* *}$ & $.891^{* *}$ & $.891^{* *}$ \\
Retailer & Sig. (2-tailed) & .000 & .000 & .000 \\
& N & 15 & 15 & 15 \\
Volume & Pearson Correlation & $.991^{* *}$ & $.995^{\star *}$ & $.995^{\star *}$ \\
Pengiriman & Sig. (2-tailed) & .000 & .000 & .000 \\
& N & 15 & 15 & 15 \\
Biaya & Pearson Correlation & $.812^{* *}$ & $.825^{* *}$ & $.825^{* *}$ \\
Distribusi & Sig. (2-tailed) & .000 & .000 & .000 \\
& $N$ & 15 & 15 & 15
\end{tabular}

Sumber: Data Primer Diolah, 2016

sesuai dengan kondisi yang diharapkan. Selain itu, DMU yang efisien mempunyai jumlah retailer yang banyak dengan volume pengiriman produk yang tinggi dan diikuti dengan biaya distribusi yang tinggi. Volume penjualan produk dari retailer juga tinggi sehingga penerimaan dan keuntungan agroindustri juga tinggi. Kondisi demikian sangat mendukung tingkat efisiensi dalam distribusi.

Saluran distribusi yang tidak efisien mempunyai nilai efisiensi $<100 \%$ yakni pada kondisi yang mungkin beresiko atau bahkan sangat beresiko. Terdapat tujuh wilayah saluran distribusi yang tidak efisien yaitu Blitar dengan score efisiensi 91,88\%, Banyuwangi dengan score efisiensi 92,69\%, Bojonegoro dengan score efisiensi $75,29 \%$, Trenggalek dengan score efisiensi $87,88 \%$, Lamongan dengan score efisiensi $90,55 \%$, Ponorogo dengan score efisiensi $91,39 \%$, dan Mojokerto dengan score efisiensi $86,32 \%$. Hal ini dikarenakan jumlah retail, volume pengiriman, dan biaya distribusi tidak sesuai dengan volume penjualan produk, penerimaan dan keuntungan yang diperoleh perusahaan serta akan merugikan perusahaan.

\section{Strategi Perbaikan pada Wilayah Distri- busi yang Tidak Efisien}

Strategi perbaikan merupakan suatu usaha dalam strategi yang digunakan sebagai acuan untuk memperbaiki tingkat efisiensi pada masing-masing DMU, sehingga DMU yang berada dalam kondisi tidak efisien mampu mencapai kondisi efisien. Strategi perbaikan sangat penting dilakukan oleh suatu perusahaan untuk memperbaiki pengalokasian atau manajemen yang kurang baik sehingga dengan adanya strategi perbaikan yang diajukan maka suatu perusahaan dapat mengalokasikan kegiatannya sesuai dengan harapan perusahaan.

Strategi perbaikan efisiensi distribusi pada agroindustri ini dilakukan menggunakan metode DEA dengan bantuan software WDEA (Warwick DEA). Metode tersebut dapat membantu melihat pencapaian tingkat efisiensi yang sesuai dengan target efisiensi suatu perusahaan sehingga dengan strategi perbaikan yang sesuai target efisiensi dapat meningkatkan tingkat efisiensi. Langkah perbaikan yang diperoleh berupa nilai actual dan nilai target efisiensi pada setiap variabel input dan output. Adapun nilai actual menunjukan nilai variabel input dan output yang sebenarnya yakni nilai yang sesuai dengan realita yang ada pada CV. Cita Mandiri. Nilai target efisiensi menunjukkan target yang seharusnya bisa dicapai pada masing-masing variabel input dan output agar efisien.

Dari ke-15 wilayah saluran distribusi, terdapat tujuh wilayah saluran distribusi yang dinyatakan tidak efisien sehingga perlu adanya strategi perbaikan untuk mencapai tingkat efisiensi yang optimal. Pada setiap wilayah saluran distribusi mempunyai strategi perbaikan yang berbeda-beda disesuaikan dengan kondisi wilayah saluran distribusi. Wilayah saluran distribusi yang tidak efisien yaitu wilayah Blitar, Banyuwangi, Bojonegoro, Trenggalek, Lamongan, Ponorogo, Mojokerto, 
Tabel 7

Hasil Perhitungan DEA dengan WDEA (Warwick DEA)

\begin{tabular}{clrcc}
\hline No & DMU & Efficiency $\%$ & Efficient & Condition \\
\hline 1. & Malang & 100.00 & Efisien & Green \\
2. & Blitar & 91.88 & Tidak Efisien & Amber \\
3. & Batu & 100.00 & Efisien & Green \\
4. & Banyuwangi & 92.69 & Tidak Efisien & Amber \\
5. & Bojonegoro & 75.29 & Tidak Efisien & Red \\
6. & Trenggalek & 87.88 & Tidak Efisien & Red \\
7. & Kediri & 100.00 & Efisien & Green \\
8. & Tuban & 100.00 & Efisien & Green \\
9. & Magelang & 100.00 & Efisien & Green \\
10. & Lamongan & 90.55 & Tidak Efisien & Amber \\
11. & Ponorogo & 91.39 & Tidak Efisien & Amber \\
12. & Mojokerto & 86.32 & Tidak Efisien & Red \\
13. & Jombang & 100.00 & Efisien & Green \\
14. & Lumajang & 100.00 & Efisien & Green \\
15. & Surabaya & 100.00 & Efisien & Green \\
\hline
\end{tabular}

Sumber: WDEA (Warwick DEA), 2016

yang ditunjukkan pada Lampiran 1. Perhitungan Data Envelopment Analysis, yang menggunakan variabel input (jumlah retailer, volume pengiriman, dan biaya distribusi), serta variabel output (volume penjualan, penerimaan, dan keuntungan), maka terdapat beberapa cara untuk meningkatkan efisiensi hingga menjadi optimal yaitu sebagai berikut:

1. Mempertahankan jumlah retailer yang ada mengingat tidak mudah mengajak pihak retailer untuk bekerjasama dengan pihak agroindustri. Mempertahankan jumlah retailer juga dapat memperluas produk di pasaran sehingga konsumen dapat cepat mengenal produk olahan buah dan sayuran.

2. Menambah jumlah retailer sehingga dapat memperluas pangsa pasar.

3. Mengurangi volume pengiriman produk karena volume pengiriman sudah sesuai dengan permintaan retailer namun produk yang dikirimkan tidak dapat terjual habis sehingga terjadi penumpukan produk. Pengurangan volume pengiriman produk dengan cara mengalihkan selisih volume produk tersebut ke wilayah saluran distribusi yang terdekat dan sudah efisien

4. Mengurangi biaya distribusi dilakukan dengan cara mengurangi volume pengiriman produk, karena biaya distribusi yang dikeluarkan sesuai dengan vol- ume pengiriman produk dan volume penjualan produk.

5. Meningkatkan volume penjualan produk dengan cara menggantikan produkproduk tidak terjual digantikan dengan produk-produk yang laku wilayah tersebut.

\section{SIMPULAN}

Kesimpulan dari analisis efisiensi distribusi pada penjualan produk olahan buah dan sayuran adalah sebagai berikut:(1) Saluran distribusi yang digunakan oleh CV. Cita Mandiri meliputi saluran distribusi nol tingkat (Produsen $\rightarrow$ Konsumen) dan saluran distribusi satu tingkat (Produsen $\rightarrow$ Retailer $\rightarrow$ Konsumen). Wilayah saluran distribusi satu tingkat meliputi wilayah Batu, Malang, Kediri, Ponorogo, Magelang, Mojokerto, Lamongan, Tuban, Bojonegoro, Surabaya, Trenggalek, Banyuwangi, Blitar, Lumajang, dan Jombang. Selanjutnya pada saluran distribusi satu tingkat dilakukan analisis efisiensi distribusi, yang menggunakan variabel input (jumlah retailer, volume pengiriman, dan biaya distribusi), serta variabel output (volume penjualan, penerimaan, dan keuntungan). (2) Hasil analisis efisiensi distribusi dengan metode Data Envelopment Analysis (DEA) menggunakan software WDEA (Warwick DEA) yaitu terdapat delapan wilayah saluran distribusi yang efisien yaitu wilayah Malang, 
Batu, Kediri, Tuban, Magelang, Jombang, Lumajang, dan Surabaya. Sedangkan terdapat tujuh wilayah saluran distribusi yang tidak efisien yaitu wilayah Blitar, Banyuwangi, Bojonegoro, Trenggalek, Lamongan, Ponorogo, dan Mojokerto. (3) Strategi perbaikan pada setiap wilayah distribusi yang tidak efisien yaitu menurunkan volume pengiriman dengan cara mengalihkan selisih volume pada wilayah saluran distribusi yang sudah efisien dan meningkatkan volume penjualan agar tidak terjadi penumpukan produk, serta menambah jumlah retailer pada wilayah distribusi yang tidak efisien. Saran yang diberikan kepada CV. Cita Mandiri dan kepada penelitian selanjutnya terkait dengan efisiensi distribusi yaitu sebagai berikut: (1) Mengurangi volume pengiriman poduk pada wilayah saluran distribusi yang tidak efisien dan menambah volume pengiriman produk pada wilayah saluran distribusi yang efisien. (3) Penambahan jumlah retailer pada wilayah distribusi yang tidak efisien.

\section{DAFTAR PUSTAKA}

Gaspersz, Vincent. 2005. Ekonomi Manajerial, Pembuatan Keputusan Bisnis. PT. Gramedia Utama. Jakarta.

Hidayati, D. 2016. Strategi Komunikasi Pemasaran Usaha Skala Mikro (Micro Enterprise) Kub Bajrah Gunah Klampis Bangkalan Pada Produk Terasi, Petis Dan Kerupuk Ikan. Agriekonomika 5(1):104 -112.

Kotler, Philip. 1983. Manajemen Pemasaran. Edisi Ke-empat Jilid Dua., Erlangga. Jakarta.

Pratiwi, I, Nandiroh, S. \& Miski, A. 2009. Analisis Efisiensi Distribusi Pemasaran Produk dengan Pendekatan Data Envelopment Analysis (DEA). Simposium Nasional RAPI 8 (1): $19-27$.

Rahardi, F. 2003. Cerdas Beragrobisnis Mengubah Rintangan menjadi Peluang Berinvestasi. PT Agromedia Pustaka. Depok.

Ray, S. 2004. Data Envelopment Analysis
Theory and Teckniques for Economics and Operrations Research.University Press. United States of America. Cambridge

Saladin,D. 1996. Unsur-unsur Inti pemasaran dan Manajemen Pemasaran. Mandar Baju. Bandung.

Santoso. 2010. Statistik Parametrik. Gramedia. Jakarta.

Sarjono, H \& Julianita, W. 2011. SPSS vs LISREL Sebuah Pengantar Aplikasi Untuk Riset. Salemba Empat. Jakarta.

Sastradipoera, Komaruddin. 2003. Manajemen Marketing Suatu Pendekatan Ramuan Marketing. Kappa-Sigma. Bandung.

Setyo Budi, Daniel. 2010. Pengukuran Efisiensi Relatif. Jurnal FE UI. Jakarta.

Simamora, Bilson. 2003. Memenangkan Pasar dengan Pemasaran Efektif dan Profitabel. PT. Gramedia Pustaka Utama. Jakarta.

Stanton, William. 1993. Prinsip Pemasaran. Erlangga. Jakarta.

Sujana, Asep. 2005. Paradigma Baru dalam Manajemen Ritel Modern. Graha IImu. Yogyakarta.

Wibow. B., S. Rusdiana. U. Adiati. 2016. Pemasaran Ternak Domba Di Pasar Hewan Palasari Kabupaten Indramayu. Agriekonomika 5(1): 85-93. 